\title{
Social Tourism Support in the Czech Republic
}

\author{
Jana Kouřilová, Lucie Kratochvílová
}

e-mail: jana.kourilova@vse.cz, xkral36@vse.cz

Department of Regional Studies, Faculty of Economics, University of Economics, Prague, Czech Republic Kourilová, J., \& Kratochvílová, L. (2014). Social Tourism Support in the Czech Republic. Czech Journal of Tourism, 3(1), 63-81. DOI: $10.2478 /$ cjot-2014-0004.

\begin{abstract}
Social tourism is a form of tourism that takes into account the participation of physically or socially handicapped individuals, and at the same time the social tourism activities are in accordance with the environmental sustainability of the territory. In the Czech Republic the social tourism has been supported at the national level since 2010 by the National Tourism Support Programme. This paper is aimed at the evaluation of social tourism support in the Czech Republic in the period of 2010-2012. The evaluation is performed by regions and target groups (families with children, young people under 26 years, seniors and the disabled). The other aim is to identify which model of social tourism was implemented in the Czech Republic during the period of 2010-2012.
\end{abstract}

\section{Keywords}

Social tourism, models of social tourism, target groups of social tourism, support of social tourism activities

JEL classification: L83 / Accepted: 19 March 2014 


\section{Introduction}

The concept of social tourism first emerged in the second half of the twentieth century. After WWII there was a worldwide boom of tourism by the inhabitants from the developed countries. Tourism became a part of the modern lifestyle and its growth has brought both economic and social benefits.

This period also saw the emergence of various organisations and associations whose aim is to remove the barriers that prevent certain population groups from participating in tourism. Although some examples of such tourism support date back to even earlier times, it is only since the 1950 s that they have been termed "social tourism".

According to the Global Code of Ethics for Tourism (UNWTO, 1999), every individual has the right to travel, and the role of social tourism activities is to make access to tourism more democratic. These activities bring their economic benefits as well: they broaden the client base of tourism businesses and help to decrease seasonal demand fluctuations, thus increasing both employment levels and the profits generated.

With the increasing numbers of persons able to participate in tourism, the definition of social tourism target groups has changed. Nowadays social tourism focuses namely on the persons who are disadvantaged in comparison to the general populace on the ground of health problems or financial limitations.

Social tourism activities are widespread in many EU countries which have numerous public and private organizations and associations to support social tourism. However, the Czech Republic is still a beginner in implementing any such measures. It has been only a few years since the Ministry for Regional Development (MRD) supported the first nationallevel social tourism programmes. The first important step was the approval of the National Support Programme of the Czech Republic 2010-2013, which entails the "Tourism for All" sub-programme. This sub-programme is aimed at promoting tourism products for disadvantaged target groups. These include children up to 15 years of age, low-income families with children, handicapped persons, youth from 15 to 26 years of age, and seniors. For four years, MRD has been providing subsidies for such projects to private businesses.

The aim of this study is to evaluate the social tourism support in the Czech Republic. It focuses on the support financed on the national level from national sources, and pays attention to the levels of the support provided for individual regions and target groups. The study does not consider social tourism activities supported by the Integrated Operational Programme and Regional Operational Programmes under the European economic and social cohesion policy.

\section{Social Tourism}

Social tourism is a form of tourism that promotes the participation of disabled or socially disadvantaged persons and does not harm the environmental sustainability of the region. Measures taken to support social tourism can be classified in two groups. First, measures that support specifically the host businesses, thus bringing mainly economic benefits, and second, measures that support the visitors, thus bringing social benefits. 
It is not simple to define social tourism because it is a very large and complicated concept and its implementation is different in various countries. According to the BITS, ${ }^{1}$ the term "social tourism" can include all phenomena and relationships resulting from the participation of disabled or financially disadvantaged persons in tourism. Page and Conell (2009) define social tourism as trips and visits made by people who would have been unable to do it without a system of outside incentives. Minnaert, Maitland, and Miller (2006) are inclined to accept the same definition, though they broadened it in 2009, specifying social tourism as those forms of tourism that benefit both the host and the guest and that embrace moral values which are not specifically present in "conventional" forms of tourism (Minnaert, Maitland, \& Miller, 2009). Almeida (in McCabe, Minnaert, \& Diekmann, 2012) emphasizes that social tourism should be supported by politicians because its main purpose is the psychological and physical recuperation of individuals who find themselves in difficult life situations. Haukeland (in McCabe, Minnaert, \& Diekmann, 2012) defines social tourism as a concept that stems from every individual's right to travel independently on his or her social or economic circumstances. The EESC ${ }^{2}$ also considers travelling to be an individual s right. (in Indrová, 2007). According to the ETLC ET $^{3}$ social tourism comprises programmes, projects and campaigns that aim to ensure the right to holiday and access to tourism to all population groups, including young people, families, senior citizens, low-income earners and individuals with limited physical capabilities.

According to Minnaert et al. (2010), everybody's right to travel is grounded in many UN documents and in UNWTO documents. Minnaert et al. (2010) see social tourism as a means of democratization and equalization among different population groups that also brings positive economic benefits. But there are also other effects, above all social effects. McCabe, Joldersma, and Li (2010), and Minnaert, Miller, and Maitland (2010) in accordance with Neal, Sirgy, and Usyal (1999) found that tourism, and in this relation especially social tourism for disadvantaged persons, contribute to approving a quality of family life, widening social contacts and acquiring new skills and experience.

According to the BITS, tourism activities have to meet these three conditions to be considered "social tourism"

1) There are barriers in society which prevent a certain group from participating in tourism - financial circumstances, disability or other types of social exclusion.

2) There are institutions that work to overcome these barriers and support the equal right to travel.

1) BITS - International Bureau of Social Tourism (Bureau International du Tourisme Social). BITS was established in 1963 and now it includes 165 members from 35 countries in Europe, Africa and North America. BITS membership is open to both public and private, profit and non-profit organizations. The Czech Republic is not represented in the BITS.

2) EESC - European Economic and Social Committee

3) ETLC- European Trade Union Liasion Comittee on Tourism

4) BITS web portal: Concepts and definitions 
3) These efforts are effective in broadening the number of persons able to participate in tourism.

For the purposes of social tourism, disadvantaged groups can be generally defined as follows: families with children, youth up to 26 years of age, seniors and the disabled $^{5}$. Individual state's social tourism policies can work with different definitions of these groups, e.g. with different age limits or disability specifications. Social tourism does not mean only the participation of disadvantaged groups in tourism, but also the activities that support their participation and remove the barriers that bar these groups from tourism. Concept of social tourism can contribute to elimination of financial difficulties which are, according to Doublet (2010), the main reason for nonparticipation in the holiday but, there are other factors such as health problems, family or job difficulties.

\section{The Principles and Functions of Social Tourism}

The principles of social tourism in the EU are laid down in the Opinion of the European Economic and Social Committee on Social Tourism in Europe ${ }^{6}$, and are in accordance with the principles formulated by the BITS at the Montreal Conference ${ }^{7}$. The main principles or purposes of social tourism are ${ }^{8}$ :

1) The basic purpose of social tourism is to increase the accessibility of tourism to persons for whom participation is difficult.

2) The disadvantaged target groups should be clearly defined (e.g. on the basis of their social circumstances, age, or disability).

3) There should be an effort to integrate tourism within the local environment in a sustainable manner.

4) Human resources management should result in improving the quality and stability of employment in tourism (i.e. it should not only produce new jobs, it should increase job stability thanks to reduced seasonal fluctuations).

From these principles it is possible to derive the functions of social tourism. According to Kratochvílová (2013), who was inspired by the classification of regional tourism impact used, e.g. by Sharma (2004), these functions can be economic, social and environmental.

The economic function - Enlarging the visitor target group through the social inclusion of disadvantaged groups brings an opportunity for businesses to gain additional profits. It also helps to decrease seasonal fluctuations in demand since some target

5) BITS web portal: The clients

6) EU web portal: The Opinion of the European Economic and Social Committee on Social Tourism

7) BITS web portal: Montreal Declaration

8) EU web portal (2006): The Opinion of the European Economic and Social Committee on Social Tourism 
groups are able to travel off-season, which increases tourism profit stability and improves employment levels throughout the year.

The social function - Social tourism supports the integration of disadvantaged population groups into the society. Although it is difficult to quantify such a support, there are studies that prove its benefits, specifically in Great Britain and Ireland (e.g. Minnaert et al., 2010; McCabe, Joldersma, \& Li, 2010). Neal, Sirgy, and Usyal (1999) produced a model that shows satisfaction with travel experience which is connected to a person's good feelings about the time spent, with a subsequent positive influence on the person's overall satisfaction levels.

The environmental function - Tourism is considered to be social when it fulfils the condition of environmental sustainability and promotes environmentally friendly forms of travel. Its positive environmental effects stem from the imperative of building sustainable tourism structures, which is one of its principles. It is not always possible to call the existing tourism structures sustainable, because many of them were built only for short-term profits, which often resulted in damage to the environment in the region. $(\text { EESC, 2006) })^{9}$

Recently, social tourism has become a hot topic in the European Union. The Opinion of the European Economic and Social Committee on Social Tourism underlines the current relevance of social tourism and includes the definitions, values and principles for promoting it. (Houška \& Petrů, 2010) In 2008, the Calypso Project was authorised for implementation. The purpose of this project is to equalize people's access to travelling and to support social tourism in the EU. Houška and Petrů (2010) describe Calypso's main goals as follows:

1) To map the best practice examples across Europe.

2) To identify current measures and to evaluate tourism participation barriers for all target groups.

3) To design a mechanism enabling the target groups to travel during low season, using off-season tours and accommodation offers.

Following the Calypso Project, April 2012 saw the establishment of the STEEP ${ }^{10}$ Programme which aims at building a coordination platform for all Calypso activities. Its web portal enables communication among various social tourism subjects and provides information on service supply and demand. ${ }^{11}$

9) EU web portal: The Opinion of the European Economic and Social Committee on Social Tourism

10) STEEP - Social Tourism European Exchanges Platform

11) The European Commission web portal: Social Tourism European Exchanges Platform (STEEP) 


\section{Social Tourism Implementation Models and Examples from the Selected EU Countries}

The EU social tourism implementation models can be divided into four basic categories, distinguished according to their product specificity and their population target groups: the participation model, the inclusion model, the adaptation model and the stimulation model. (Minnaert, Maitland, \& Miller, 2011)

The participation model focuses on including disadvantaged groups in activities that are regularly accessible to other citizens. It does not promote the formation of new products; it only seeks ways to remove barriers that prevent the access to already existing products. The consumption of these products is conditioned by meeting certain criteria of a disadvantaged participant (and, of course, it depends on the removal of barriers and the establishment of a support programme).

This model can be observed in practice in Belgium. Belgium's central social tourism organization is the Holiday Participation Centre (HPC) which was founded in 2001 and is financed by the government. Its main target group is low-income citizens and the HPC products are not accessible to common non-disadvantaged citizens ${ }^{12}$. The main initiatives are thus introduced on a volunteer basis by companies such as hostels, hotels, event organizers, or children's holiday camp organizers. (Minnaert, Maitland, \& Miller, 2011). The persons interested in using HPC services must meet certain criteria, e.g. low income, unemployment, low education, or health problems. The participants contribute financially to all projects, not only for economic reasons, but also in order to increase their involvement and responsibility. (Ramboll, 2010)

The inclusion model is based on the broadest possible general tourism support. This means the development of standard products which are open to all, not just to disadvantaged population groups. This model includes both activities aimed at supporting the travel of disadvantaged citizens, and activities that support the travel of citizens who are not facing any financial or medical problems. This model is employed mainly in France. The French national social tourism support focuses on all age groups - families with children, youth, seniors and the disabled.

French social tourism support is in the competence of the ANCV ${ }^{13}$ which was founded in 1982 by the Ministry of Economy, Finances and Industry. The ANCV has the following functions (Doublet, 2010):

It administers holiday vouchers, which are given by employers to employees through the ANCV (holiday vouchers are VAT-exempt). The vouchers are issued for various tourism services - accommodation, transport, boarding or entrance fees.

It developed specific programmes aimed at disadvantaged groups:

- Seniors en vacances (Seniors on holiday),

- Aides aux projets vacances (Support for holiday projects),

- Bourse solidarité vacances (Solidarity holiday grant),

- Support of tourism facilities.

12) The Holiday Participation web portal: Who is eligible?

13) ANCV - L'Agence Nationale pour les Chèques Vacances (National Holiday Vouchers Agency) 
In cooperation with public administration authorities, the ANCV carries out the project "Vacances et Handicapes" with the purpose of providing concise and objective information on the accessibility of tourist sights and facilities to disabled persons. ${ }^{14}$

The VACAF (Les aides aux vacances) is the main public support system for low-income families with children. Its network of accommodation facilities offers reduced prices to these families in all regions of France. (Doublet, 2010)

The adaptation model is a system of incentives consisting of tourism products which are available to disadvantaged groups only, while other citizens cannot use them. The products are designed to meet the specific requirements of various disadvantaged groups. An example of this approach can be found in Great Britain and its special holiday programmes for disabled children and children from low-income and/or socially excluded families.

The most important organization in Great Britain is the non-profit Family Holiday Association (FHA) which supports the inclusion of low-income families in tourist activities. Its philosophy is based on the idea that holidays help to strengthen family relationships, improve the health of family members and increase their overall satisfaction, with a subsequent positive impact on the general society. The FHA was established in 1975 and focuses on providing package tours (Minnaert et al., 2010). This organization is not financially supported by the state. It gets a financial support from corporate donations (40\%) and individuals (31\%), and the rest of its funding comes from its own activities.

The purpose of the stimulation model is to broaden the visitor target group and thus help tourism businesses to earn a higher income, reduce seasonal fluctuations and make better use of facility capacities. The highest attention is paid to the development of specialized programmes that could attract new visitors.

An example of this approach is Spain where the social tourism support focuses mainly on senior citizens. The 1980s saw the establishment of the IMSERSO programme with the main purpose of improving the quality of life for the retired citizens by supporting their tourism participation. Since 2008 the programme has been open to senior citizens from the whole Europe; they can choose from a large offer of package tours to Spain, Portugal or the Canary Islands. These subsidized programmes provide seniors with complex service packages including transport, insurance, accommodation and organized social events during their holiday stay. ${ }^{15}$

\section{Methodology}

The aim of this article is to evaluate the social tourism support in the Czech Republic. It focuses on the support financed on the national level from national sources, and pays attention to the levels of the support provided for individual regions and target groups. The other aim is to identify which model of social tourism was implemented in the Czech Republic during the period of 2010-2012.

14) Vacances et Handicapes web portal.

15) Abacotaxes web portal: Subsidised holidays in Spain 
In this research all projects supported in the period of 2010-2012 were analysed according to the following criteria:

- their localization,

- their budget,

- target groups,

- supported activities with attention to the year-round activities.

Finally, all data were aggregated at the NUTS 3 level. This regional level serves as a basic unit for comparison of social tourism support.

The data of this research were obtained from the Ministry for Regional Development of the Czech Republic [MRD], which publishes them on its website.

\section{Social Tourism Support in the Czech Republic}

In the Czech Republic, social tourism support was first implemented on a regional level. The first Czech social tourism project "Beskydy for All" was focused on barrier-free travelling in the region of Beskydy. The project started in 2005 with financial support from the European Social Fund ${ }^{16}$ and produced a clear labelling system to inform customers about the quality of services offered, and came up with a "Barrier Free" label that was awarded to tourist facilities in the region which met the required criteria (approximately 20 facilities). The project team also published a Travel Manual with information on tourist sights, facilities and services, including information on their accessibility to disabled visitors. An educational programme was established to offer training in providing special services to disabled visitors and in the communication skills. These activities were then followed by the "Moravia and Silesia for All" programme, which included 100 facilities in total (Gombitová, 2010). Since then, several similar projects have been established to provide disadvantaged groups with clear and concise information about the accessibility of tourist facilities and sights.

The first step to support Czech social tourism on a national level was taken when the MRD started the "Tourism for All" programme in 2010. It is aimed at the following target groups (MRD, 2010c):

- children (up to 15 years of age);

- youth (15-26 years of age);

- low-income families with children ${ }^{17}$;

- seniors (60 years and over);

- disabled citizens - persons suffering from mobility impairments, sensory impairments (hearing or vision impairments), mental handicaps or other serious health problems (allergies, diabetes, respiratory illnesses, etc.).

It is clear that each target group has their specific travelling requirements which are sometimes quite divergent.

16) The "Beskydy.cz" website, http://bez-barier.beskydy.cz/Content/handicap_search.aspx,

17) In the first year the programme included families which qualified for child welfare benefits; in later years it included all families with children 


\section{Social Tourism Support on the National Level: The "Tourism for All" Sub-pro- gramme}

The State Tourism Policy Concept for 2007-2013 defines social tourism as efforts to “include persons from low-income groups in tourism activities”. (MRD, 2007, p. 46)

In 2010, this definition was broadened in the National Support Programme of the Czech Republic 2010-2013 to incorporate all efforts aimed at the inclusion of citizens who are disadvantaged on the basis of health problems, e.g. disabled citizens and seniors. This programme gave rise to the "Tourism for All" sub-programme, administered by the MRD. The Ministry awards grants to businesses that work to support tourism activities of disadvantaged target groups, and the programme thus should be an effective means of social tourism support (MRD, 2010a).

The programme's main goals for its first implementation year complied with the principles of social tourism as defined by the EC and BITS (MRD, 2010b):

- To make tourism accessible to disadvantaged population groups and to include new target groups.

- To encourage the expansion of tourism within the Czech Republic and the development of new products with the purpose of reducing seasonal fluctuations.

- To create conditions favourable for creating non-seasonal jobs in tourism.

- From 2011 onward, these have been supplemented by two more goals (MRD, 2011b):

- To create economic conditions that would make it possible to improve the offer of additional tourism infrastructure: building or reconstructing rest-areas and sanitary facilities for hikers, cyclists and disabled tourists alongside the hiking routes, nature trails and cycling lanes.

- To make attractive tourist sights accessible for all in a way that is environmentally friendly.

The maximum sum assigned to the programme for year 2010 was 100 million CZK (MRD, 2010c). This sum was later reduced: in 2011 the programme had only 72 million CZK (MRD, 2011a) and in 2012 only 60 million CZK (MRD, 2012). The total cost of the supported project was required to range from 250 thousand to five million CZK, and the grant given could not cover more than a half of the project costs. The tourism products and services which were developed using state grants had to be implemented by the end of the following year. The grants were also used to cover a part of the project promotion costs. (MRD, 2010b)

The grants were available to both legal and natural persons doing their business activities in the Czech Republic in the following CZ NACE categories ${ }^{18}$ (MRD, 2010c):

- 55 - Accommodation,

- 56 - Restaurants and food service activities,

- 79 - Travel agency activities, tour operator activities, other reservation services and related activities.

18) CZ NACE is a statistical classification of economic activities prepared in compliance with Regulation No. 1893/2006 of the European Parliament and of the Council. 
In 2011 this requirement was changed and the grants were made available to every legal person (listed in the business register) and every natural person doing their business activities in compliance with Act No. 455/1991 Coll. on Trades, or with other legal regulations. (MRD, 2011a) Successful applicants had to meet further conditions to show that they were able and likely to implement and sustain the project (no debts towards the state budget, state funds and health insurance companies, positive economic results in two latest accounting periods, separate accounting records for eligible and non-eligible costs, or no insolvency proceedings against the applicant). The grant was strictly restricted to the stipulated purpose - the project had to be continued and sustained at least for 5 years in the form in which it was presented by the applicant. In case the project was terminated early, the property could not be used for other purposes. (MRD, 2010c)

\section{The Implementation of the Sub-programme and its Regional Dimension}

Between 2010 and 2012, grants were awarded to 113 projects, with total expenditure of 181 million CZK. See the following table (Figure 1) for details:

Figure 1 Sub-programme implementation 2010-2012

\begin{tabular}{|l|c|c|c|}
\hline & $\mathbf{2 0 1 0}$ & $\mathbf{2 0 1 1}$ & $\mathbf{2 0 1 2}$ \\
\hline Number of projects implemented & 36 & 42 & 35 \\
\hline Total sum in millions of CZK & 64.3 & 68.7 & 48.4 \\
\hline
\end{tabular}

Source: MRD

In 2010 the total expenditure was 64.3 million CZK. The MRD received 83 applications in total, amounting to 151.9 million CZK. Grants were awarded to 36 projects. (MRD, 2011c) Out of these, 11 projects were designed to support tourism in the whole Czech Republic, crossing regional borders. These were intermediary services with products such as travel packages for social tourism target groups, web portals with tourist information and reservation service, or a net of hotels that offer discounts for disadvantaged groups or that are able to provide special food services for clients with specific health requirements. The total expenditure for these projects was 20.9 million CZK. Other grants went to eight regions. The regional distribution, however, was quite uneven (there were no successful projects in the Olomoucký, Vysočina, Ústecký and Pardubický regions).

In 2011, the total sum awarded to the projects slightly increased to 68.7 million CZK. Grants were given to 42 projects. The sub-programme spread almost to all regions; Prague was the only region without a successful project. The Jihočeský region was the most successful; it had the largest number of successful projects and won the largest amount of funds. The projects aimed to support regional tourism. There were no national-level projects as in 2010.

In 2012, the total sum of the awarded funds decreased approximately by 20 million 
CZK. The total sum awarded was 48.4 million CZK. The sub-programme supported 35 projects from all regions except for the Karlovarský region. The Jihočeský region again achieved the largest number of successful projects and won the largest amount of funds.

Figure 2 The distribution of grants (the number of projects, the funds granted) in regions in 20102012

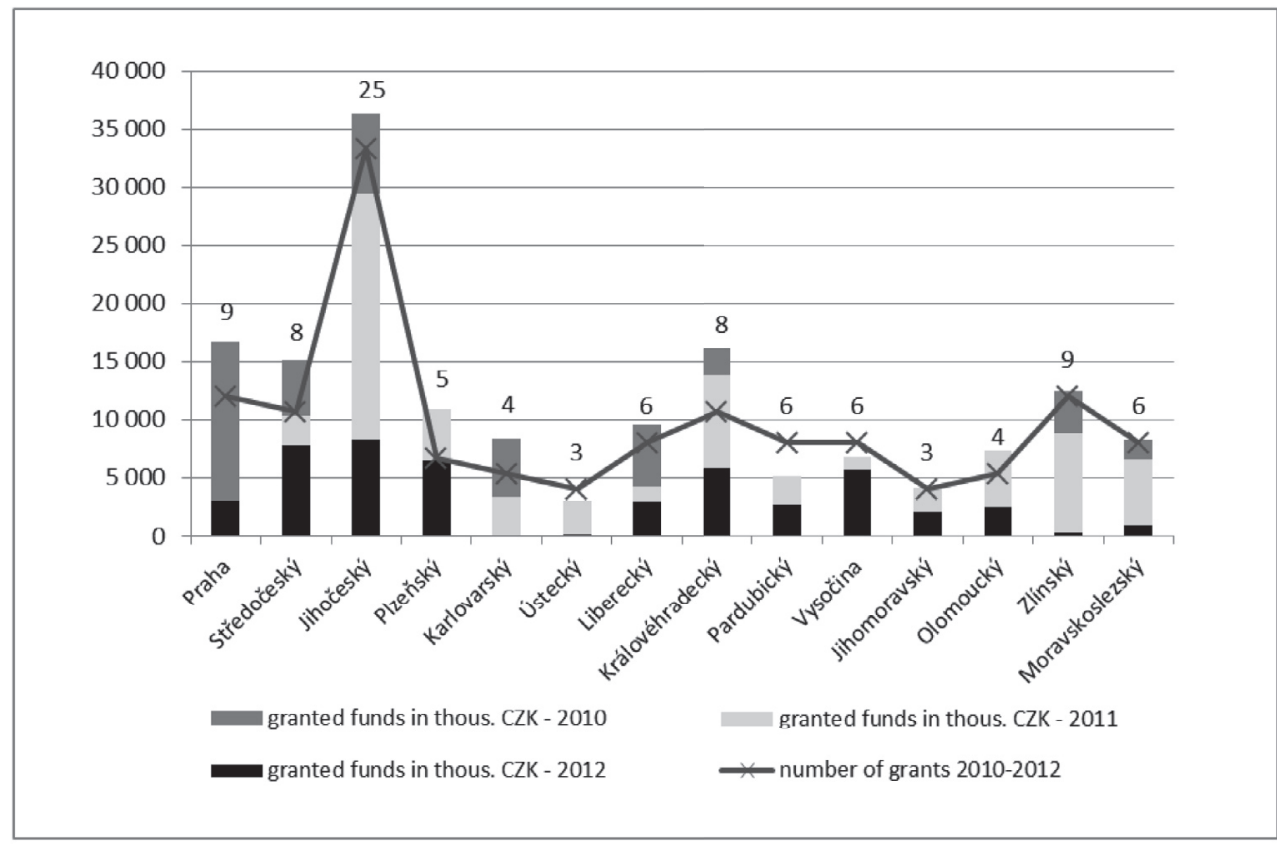

Source: the authors' graph based on MRD data

\section{The Distribution of Grants to Target Groups and Seasonal Products}

One of the goals of the grant programme is to include new participant groups in tourism activities. As it is shown in Figure 3, the 2010 projects focussed their products on specific target groups. Since 2011 the projects have been focussed on a wider client base, including three or more target groups. It can be concluded that in 2010 the Czech situation corresponded to the adaptation mode, because there were projects intended for one-two target groups, while in 2011 and 2012 it was possible to see a transition to the inclusion model. 
Figure 3 Overall distribution of grants according to the number of target groups

\begin{tabular}{|l|c|c|c|}
\hline \multirow{2}{*}{ The number of target groups } & \multicolumn{3}{|c|}{ The number of projects } \\
\cline { 2 - 4 } & $\mathbf{2 0 1 0}$ & $\mathbf{2 0 1 1}$ & $\mathbf{2 0 1 2}$ \\
\hline $\mathbf{1}$ & 10 & 2 & 1 \\
\hline $\mathbf{2}$ & 11 & 2 & 2 \\
\hline $\mathbf{3}$ & 6 & 11 & 11 \\
\hline $\mathbf{4}$ & 4 & 9 & 7 \\
\hline $\mathbf{5}$ & 5 & 18 & 14 \\
\hline
\end{tabular}

Source: the authors' table based on MRD data (2013a)

Figure 4 shows the trends in the distribution of grants among the target groups in the consequent years. It is indicative only because even if a project is aimed primarily at a certain target group, e.g. families with children, it can serve to support tourist activities of other groups as well, e.g. youth or seniors (for example, family bicycle touring facilities).

Figure 4 Overall distribution of grants to different target groups

\begin{tabular}{|l|c|c|c|c|c|c|c|c|}
\hline \multirow{2}{*}{ Target group } & \multicolumn{4}{|c|}{ The number of projects } & \multicolumn{4}{c|}{$\begin{array}{c}\text { The percentage in the total } \\
\text { number of projects }\end{array}$} \\
\cline { 2 - 9 } & $\mathbf{2 0 1 0}$ & $\mathbf{2 0 1 1}$ & $\mathbf{2 0 1 2}$ & Total & $\mathbf{2 0 1 0}$ & $\mathbf{2 0 1 1}$ & $\mathbf{2 0 1 2}$ & Total \\
\hline Children & 26 & 38 & 34 & $\mathbf{9 8}$ & $72 \%$ & $90 \%$ & $97 \%$ & $\mathbf{8 7} \%$ \\
\hline Youth & 17 & 35 & 27 & $\mathbf{7 9}$ & $47 \%$ & $83 \%$ & $77 \%$ & $\mathbf{7 0} \%$ \\
\hline Families with children & 19 & 39 & 34 & $\mathbf{9 2}$ & $53 \%$ & $93 \%$ & $97 \%$ & $\mathbf{8 1} \%$ \\
\hline Seniors & 17 & 27 & 23 & $\mathbf{6 7}$ & $47 \%$ & $64 \%$ & $66 \%$ & $\mathbf{5 9} \%$ \\
\hline The disabled & 12 & 26 & 18 & $\mathbf{5 6}$ & $33 \%$ & $62 \%$ & $51 \%$ & $\mathbf{5 0} \%$ \\
\hline
\end{tabular}

Source: the authors' table based on MRD data (2013a)

The largest number of the projects was aimed to support tourism activities of families with children. The most frequent products for this group were services and facilities for cyclists and hikers (e.g. sport equipment rental service, children's playgrounds, sanitary facilities, information centres, trail blazing). Other holiday activities were supported as well: canoeing, mountain climbing, horse riding or skiing. These activities benefited also from the grants that supported sightseeing tourism or the building of special entertainment and arts centres (pottery workshops or playrooms). Many of these facilities can be used by young people and seniors, too. 
Youth as a specific target group was served by the National Support Programme only in the first year of the sub-programme implementation. It was the only year when special products were prepared for this target group only. However, young people can use products prepared for other target groups, such as for families with children.

Products for seniors are often focused on mobility impairments, i.e. on providing facilities which can make transport easier: low-floor buses, ecological trains, electric bikes. Another important product was wheelchair accessible sanitary facilities which serve two target groups at once: seniors and the disabled. Other products focussed on seniors included spa stays, sightseeing packages and suitable sport activities, e.g. nordic walking.

As it is shown in Figure 4, the least supported target group is the disabled. This is probably caused by the fact that special facilities for the disabled are not very useful for other visitors. There were only four successful projects that were aimed exclusively at the disabled tourists. That is why products for the disabled were usually included in the projects focused on the other target groups. Most projects dealt with mobility impairments, four projects included a tourism support for visitors with vision impairments and two projects were designed for the visitors with hearing impairments.

Figure 5 gives an overview of the basic project information for various target groups and regions: Jihočeský has a prominent position in all target group categories, which corresponds to its success in winning grants. On the contrary, the Ústecký and Karlovarský regions rank the lowest.

Figure 5 Successful projects according to target groups and regions, 2010-2012

\begin{tabular}{|c|c|c|c|c|c|c|c|c|c|c|}
\hline \multirow[t]{2}{*}{ Region } & \multicolumn{2}{|c|}{ Children } & \multicolumn{2}{|c|}{ Youth } & \multicolumn{2}{|c|}{$\begin{array}{l}\text { Families with } \\
\text { children }\end{array}$} & \multicolumn{2}{|c|}{ Seniors } & \multicolumn{2}{|c|}{ The disabled } \\
\hline & number & $\%$ & number & $\%$ & number & $\%$ & number & $\%$ & number & $\%$ \\
\hline Prague & 6 & 67 & 4 & 44 & 5 & 56 & 2 & 22 & 2 & 22 \\
\hline Středočeský & 8 & 100 & 7 & 88 & 8 & 100 & 6 & 75 & 6 & 75 \\
\hline Jihočeský & 22 & 88 & 19 & 76 & 22 & 88 & 16 & 64 & 13 & 52 \\
\hline Plzeňský & 5 & 100 & 3 & 60 & 5 & 100 & 3 & 60 & 3 & 60 \\
\hline Karlovarský & 3 & 75 & 1 & 25 & 2 & 50 & 4 & 100 & 1 & 25 \\
\hline Ústecký & 2 & 100 & 3 & 100 & 2 & 100 & 2 & 67 & 2 & 67 \\
\hline Liberecký & 5 & 83 & 5 & 83 & 4 & 67 & 3 & 50 & 2 & 33 \\
\hline Královéhradecký & 7 & 100 & 5 & 71 & 7 & 100 & 6 & 86 & 6 & 86 \\
\hline Pardubický & 6 & 100 & 6 & 100 & 6 & 100 & 2 & 33 & 1 & 17 \\
\hline Vysočina & 6 & 100 & 5 & 50 & 6 & 100 & 2 & 33 & 1 & 17 \\
\hline Jihomoravský & 3 & 100 & 5 & 67 & 3 & 100 & 2 & 67 & 2 & 67 \\
\hline Olomoucký & 4 & 100 & 4 & 100 & 4 & 100 & 3 & 75 & 3 & 75 \\
\hline Zlínský & 7 & 88 & 5 & 63 & 6 & 75 & 4 & 50 & 6 & 75 \\
\hline Moravskoslezský & 6 & 100 & 5 & 83 & 6 & 100 & 5 & 83 & 4 & 67 \\
\hline
\end{tabular}

Source: the authors' table based on MRD data (2013a) 
One of the goals of the National Support Programme is to reduce the seasonal fluctuation and to support year-round tourism activities. The highest percentage of such projects was in 2010, while the following years saw a decrease. (Figure 6)

Figure 6 The number of projects supporting year-round activities

\begin{tabular}{|l|c|c|}
\hline Year & $\begin{array}{c}\text { The number of projects supporting } \\
\text { year-round activities }\end{array}$ & $\begin{array}{c}\text { The percentage of projects } \\
\text { supporting year-round activities }\end{array}$ \\
\hline $\mathbf{2 0 1 0}$ & 24 & $69 \%$ \\
\hline $\mathbf{2 0 1 1}$ & 15 & $36 \%$ \\
\hline $\mathbf{2 0 1 2}$ & 14 & $37 \%$ \\
\hline
\end{tabular}

Source: the authors' table based on MRD data (2013a)

The seasonal fluctuation can be reduced by making tourist activities available off-season to new target groups. For example, if tourists object and facilities are accessible to the disabled or to seniors, these groups can be expected to prefer to make their holidays in the peaceful off-season.

\section{Results: Evaluation of the Sub-programme Implementation in 2010-2012}

On the basis of the analysis of the social tourism support in the period of 2010-2012 in the Czech Republic, it can be concluded that:

- A significant amount of the grant funds was used in the Jihočeský region and in Prague, which are the regions with high tourist turnout. The regions with low tourist turnout got less support (e.g. the Vysočina region);

- All target groups were supported in every region, but the support they received differed in scope. All regions focused predominantly on families with children (except for the Karlovarský region and Prague). The Královéhradecký, Karlovarský and Moravskolezský regions presented projects oriented more towards seniors. The lowest percentage of projects for seniors can be found in Prague, the Vysočina and the Pardubický regions. All regions did not have many projects focused on disabled tourists;

- The 2010 projects focused their products on specific target groups. Since 2011 the projects have been focused on a wider client base, including three or more target groups. In 2010 the Czech situation corresponded to the adaptation model, while 2011 and 2012 saw a transition to the inclusion model;

- All regions except for the Pardubický region had at least one successful project that supported year-round tourism activities, particularly in spring and summer;

- The most frequently supported type of tourism is an active holiday. At least one new sport equipment rental service was built in every region. The highest number of these - eleven - was built in the Středočeský region. The second most frequently supported 
product was new rest areas built alongside the cycling lanes and hiking routes (except for the Jihomoravský and the Ústecký region). Other frequent products included playgrounds, sport facilities, bicycle storage facilities or bicycle parking racks. There has been a strong boost of cycle tourism, hiking and walking in all regions. From the environmental point of view, it is positive that other forms of ecological transport besides the cycle tourism were supported in seven regions.

\section{Discussion}

As it has been already mentioned, the main purpose of social tourism is to make tourism accessible to new population groups, while respecting the basic principles of the sustainable development. At the same time, it should work to decrease the seasonal fluctuations of the tourist turnout by supporting year-round activities. The decreased fluctuation should lead to an increase in employment levels and incomes from tourism. In the context of results of support social tourism evaluation, a question can be asked whether social tourism support in the Czech Republic fulfils the goal and principles of social tourism.

It is possible to conclude that the main goals of the Czech National Support Programme comply with the principles established by the BITS and the European Commission. However, these goals have been only partially achieved because the programme still suffers from some imperfections.

Among the positive aspects of the programme are the participation of business entities from all regions in 2010-2012, the support of projects for all target groups, the support of sustainable tourism projects and the effort to develop year-round activities.

On the contrary, the support has not been distributed in a balanced way among the regions and among the target groups. The largest amount of funds went to the Jihočeský region and Prague, which are both quite popular tourist destinations. It is difficult to say if this situation was caused by insufficient information or experience by the applicants from other regions, or if it was caused by other factors. It is necessary to look for the reasons of this discrepancy and for ways to eliminate these barriers.

When looking at the overall orientation of the projects, it is possible to see that those population groups that face the most difficulties in tourism received the least support. This may have been partially due to the enlargement of the programme in 2011, which entailed the removal of the condition of low income for the support of families with children, thus moving the programme further away from the basic purpose of social tourism. The lowest number of projects was focused on the disabled. If the disabled do not have access to essential services (e.g. wheelchair accessible sanitary facilities), they basically cannot participate in tourism. The same situation is faced by seniors with mobility impairments. The question is whether and how it can provide a stronger support to future projects focused on these neglected target groups.

Another problem which has surfaced during the research for this paper is insufficient promotion of new products. Although the project owners used various forms of promo- 
tion, many of them do not have up-to-date project information on their websites, which simply lowers their opportunities for making effective use of the products. It is not only the presentation of individual project owners that is insufficient. The Czech project owners are not connected to one another, lacking the interconnected web that has been so helpful in implementing social tourism support in Spain or Great Britain. It would be useful to create a national database of social tourism facilities which would include information on their accessibility to various social tourism target groups, as well as a unified and simple labelling system of facilities and tourist objects.

The implementation of the National Support Programme in 2010-2013, or its "Tourism for All" sub-programme, can be viewed as a successful first step towards social tourism support in the Czech Republic, but basic goals and principles of social tourism have been achieved only partially.

\section{Conclusion}

The concept of social tourism first emerged in the second half of the twentieth century. After WWII there was a worldwide boom of tourism by the inhabitants from the developed countries. Tourism became a part of the modern lifestyle and its growth has brought both economic and social benefits.

The main principles or purposes of social tourism $\operatorname{are}^{19}$ :

1) To increase the accessibility of tourism to persons for whom participation is difficult.

2) The disadvantaged target groups should be clearly defined.

3) There should be an effort to integrate tourism within the local environment in a sustainable manner.

4) Human resources management should result in improving the quality and stability of employment in tourism.

From these principles, it is possible to derive the functions of social tourism: economic, social and environmental. The economic function associated with enlarging the visitor target group through the social inclusion of disadvantaged groups brings an opportunity for businesses to gain additional profits. The social function of social tourism supports the integration of disadvantaged population groups into the society. The environmental function means the fulfilment of the condition of environmental sustainability and a promotion of environmentally friendly travel forms. Its positive environmental effects stem from the imperative of building sustainable tourism structures, which is one of its principles.

In the EU social tourism implementation can be distinguished by four basic models according to their product specificity and their population target groups: the participa-

19) EU web portal (2006): The Opinion of the European Economic and Social Committee on Social Tourism 
tion model, the inclusion model, the adaptation model and the stimulation model. (Minnaert, Maitland, \& Miller, 2011)

The purpose of this study is to evaluate the social tourism support in the Czech Republic in the period of 2010-2012. It specifically focuses on the support financed on the national level from national sources, and pays attention to the levels of support provided for individual regions and target groups. The other aim is to discover which model of social tourism was implemented in the Czech Republic during the period of 2010-2012.

In the Czech Republic, social tourism support was first implemented on a regional level. The first step to support Czech social tourism on a national level was taken when the MRD started the "Tourism for All" programme in 2010. It is aimed at the following target groups (MRD, 2010c): children, youth, low-income families with children, seniors and disabled persons. In this article all supported projects were analysed under their localization, budgets, target groups and supported activities with attention to year-round activities.

On the basis of this analysis, it is possible to conclude that regionally a significant amount of the grant funds was used in the Jihočeský region and in Prague, which are both regions with high tourist turnout. In every region all target groups were supported and all regions also focused predominantly on families with children (except for the Karlovarský region and Prague). The Královéhradecký, Karlovarský and Moravskolezský regions presented projects oriented more towards seniors.

The lowest number of projects was focussed on the disabled. If the disabled do not have access to essential services (e.g. wheelchair accessible sanitary facilities), they basically cannot participate in tourism. This is a barrier not only for the disabled but also for seniors with mobility impairments. These two groups are limited in their participation in tourism in the Czech Republic.

The most frequently supported type of tourism is an active holiday. All regions except for the Pardubický region had at least one successful project that supported year-round tourism activities, particularly in spring and summer.

One of the goals of the grant programme was to include new participant groups in tourism activities. The 2010 projects focused their products on specific target groups. Since 2011 the projects have been focused on a wider client base, including three or more target groups. In 2010 the Czech situation could be assessed according to the adaptation model, while 2011 and 2012 saw a transition to the inclusion model.

Finally, it can be concluded that the implementation of the National Support Programme in 2010-2013, or its "Tourism for All” sub-programme, can be viewed as a successful first step towards social tourism support in the Czech Republic. Its basic goals and principles have been at least partially achieved and followed, and the programme has thus created a platform for the development of new activities. This development, however, will be largely dependent on the amount of funds made available for its support by the MRD. As it has been already mentioned above, the funding has been steadily decreasing each year, and at this moment it is not clear whether the support programme continues in 2014. If it does, it might be worthwhile to give some thought to a few issues mentioned in this paper. 


\section{Acknowledgement}

This paper has been prepared within the IG507013 project "Approaches to implementing regional development strategies" (Vývoj př́stupů k naplnění strategií regionálního rozvoje), IGA VŠE.

\section{References}

Abacotaxes web portal. Subsidised holidays in Spain. Retrieved from <http://www.abacotaxes. com/subsidised-holidays-spain-imserso> (13/7/2013).

Beskydy cz. Retrieved from 〈http://bez-barier.beskydy.cz/Content/handicap_search.aspx> (20/10/2013).

Doublet, M. (2010). Calypso study on Social Tourism, France. National Contact Point.

The European Commission web portal. Social Tourism European Exchanges Platform (STEEP) Retrieved from <http://ec.europa.eu/enterprise/sectors/tourism/calypso/activities/documents_calypso/steep_summary_en.pdf> (16/7/2013).

The European Trade Union Liasion Committee on Tourism web portal. Retrived from http:// www.etlc-network.eu/themen/social_tourism (19/2/2014).

The European Union web portal (2006). Stanovisko Evropského hospodářského a sociálniho výboru k tématu Sociálni cestovni ruch v Evropě, (2006/C 318/12). Retrieved from <http://eurlex.europa.eu/LexUriServ/LexUriServ.do?uri=OJ:C:2006:318:0067:0077:CS:PDF> (24/6/2013).

Family Holiday Association web portal. Charity Information. Retrieved from <http://www.familyholidayassociation.org.uk/charity-information> (13/6/2013).

Gombitová, D. (2010). Calypso study on Social Tourism, The Czech Republic. HAMS

Holiday Participation Center web portal. Who is eligible? Retrieved from <http://www.holidayparticipation.eu/> (3/6/2013).

Houška, P., \& Petrů, Z.(2010). Cestovni ruch v působnosti orgánů EU (selected documents). 1st ed. Prague: Oeconomica.

Indrová, J. (2007). Cestovni ruch. 1st ed. Prague: Oeconomica.

The International Bureau of Social Tourism (BITS) web portal: The Clients. Retrieved from <http:/ / www.bits-int.org/en/index.php?menu=1\&submenu=4> (13/6/2013).

The International Bureau of Social Tourism (BITS) web portal: Montreal Declaration. Retrieved from 〈http://www.bits-int.org/files/b62950f2634ad799d24c3d2485f21644_1177346617.pdf> $(8 / 6 / 2013)$.

The International Bureau of Social Tourism (BITS) web portal: Concepts and definitions. Retrieved from <http:/ www.bits-int.org/en/index.php?menu=1\&submenu=2> (13/6/2013).

Kratochvílová, L. (2013). Sociálni cestovni ruch v krajich České republiky. Master thesis. Prague: University of Economics.

McCabe, S., Joldersma, T., \& Li, C. (2010). Understanding the benefits of social tourism: Linking participation to subjective well-being and quality of life. International Journal of Tourism Research, 12(6), 761-773. DOI: 10.1002/jtr.791.

McCabe, S., Minnaert, L., \& Diekmann, A. (Eds.). (2012). Social Tourism in Europe: Theory and Practise (Aspects of Tourism). Bristol: Channel View Publications. 
Minnaert, L., Maitland, R., \& Miller G. (2006). Social tourism and its ethical foundations. Tourism, Culture and Communication, 7(12), 7-17. Retrieved from http://ebookbrowse.com/minnaert-maitland-miller-2006-final-pdf-d319703705.

Minnaert, L., Maitland, R., \& Miller G. (2009). Tourism and Social Policy: The Value of Social Tourism. Annals of Tourism Research, 36(2), 316-334. DOI: 10.1016/j.annals.2009.01.002.

Minnaert, L. et al. (2010). Social tourism for low-income groups: benefits in a UK and Irish context. In C. Stroma \& M. Nigel (Eds.), Tourism and inequality: problems and prospects (pp. 126 142). Wallingford/Cambridge: CABI.

Minnaert, L., Maitland, R., \& Miller, G. (2011). What is social tourism? Current Issues in Tourism, 14(5), 403-415. DOI: 10.1080/13683500.2011.568051.

Neal, J., Sirgy, M. J., \& Uysal, M. (1999). The role of satisfaction with leisure travel/tourism services and experience in satisfaction with leisure life and overall life. Journal of Business Research, 44(3), 153-163. DOI: 10.1016/S0148-2963(97)00197-5.

Page, S. J., \& Connel, J. (2009). Tourism. A modern synthesis. Andover: Cengage Learning EMEA.

Ramboll (2010). Calypso study on Social Tourism, Belgium (Country study). Retrieved from http:// ec.europa.eu/enterprise/sectors/tourism/files/calypso/country-reports/belgium_en.pdf.

Sharma, K.K. (2004). Tourism and Regional Development. New Delhi: Sarup \& Sons.

Ministry for Regional Development (MRD). (2007). Koncepce státni politiky cestovního ruchu v České republice na obdobi 2007-2013 (The conception of state tourism policy in the Czech Republic for years 2007-2013). Prague: Ministry for Regional Development. Retrieved from http://www.mmr.cz/ getmedia/fe9ed7fd-a7b8-43f3-95ae-e0adbbbbc0e5/III-_Koncepce_7-11-07.pdf.

Ministry for Regional Development (MRD). (2010a). MMR startuje podporu SCR. Retrieved from http://www.mmr.cz/cs/Ministerstvo/Ministerstvo/Pro-media/Tiskovezpravy/2010/ MMRstartuje-podporu-socialniho-cestovniho-ruchu.

Ministry for Regional Development (MRD). (2010b). Národni program podpory CR 2010-2013. Retrieved from <http://www.mmr.cz/getmedia/3de96b76-d826-4874-ae03-6b36633d7612/ NPPCRPrezentace-Seminar.ppt> (23/7/2013).

Ministry for Regional Development (MRD). (2010c). Zásady pro žadatele o poskytnuti dotace. Retrieved from <http://www.mmr.cz/getmedia/82596be4-1c4f-420f-a40b-0058dbf7519b/Zasady_1.pdf> (13/6/2013).

Ministry for Regional Development (MRD). (2011a). Národni program podpory CR 2010-2013,. Retrieved from <http:/ /www.mmr.cz/getmedia/007b0c7e-1e08-4d5e-be85-0c01c3d1bc63/ NPPCRPrezentace-seminar-4-5-2011.pdf $>(23 / 7 / 2013)$.

Ministry for Regional Development (MRD). (2011b). Zásady pro žadatele o poskytnutí dotace.. Retrieved from <http://www.mmr.cz/getmedia/dbccdc74-0d52-491a-8a79-8f7016a078be/Zasadyprozadatele.pdf> (13/6/2013).

Ministry for Regional Development (MRD). (2011c). Cestovni ruch v České republice 2010.. Retrieved from <https://www.mmr.cz/getmedia/8132d133-1d94-4af6-94b7994c1dafc2f3/Rocenka_2.pdf> (13/6/2013).

Ministry for Regional Development (MRD). (2012). Národni program podpory CR 2010-2013. Retrieved from <http:/ /www.mmr.cz/getmedia/3de96b76-d826-4874-ae03-6b36633d7612/ NPPCRPrezentace-Seminar.ppt> (3/7/2013).

Vacances et Handicapes web portal. Retrieved from <http://www.ufcv.fr/Vacances/VacancesetHandicap.aspx> (15/7/2013). 